\title{
Use of Feedback in Physical Education and Sports Lessons for Student Point of View
}

\author{
Murat Kangalgil, Fatih Özgül* \\ Department of Physical Education and Sports, Cumhuriyet University, Sivas, Turkey
}

Copyright $\bigcirc 2018$ by authors, all rights reserved. Authors agree that this article remains permanently open access under the terms of the Creative Commons Attribution License 4.0 International License

\begin{abstract}
The most important element of the education system is education itself, the process through which student behaviours are acquired. One of the most crucial and effective elements in this learning process is feedback. Feedback to students is at the centre of much research that discusses interaction between student and teacher behaviour. In physical education and sports lessons, it is particularly important for the student to be given proper feedback, because it will affect skill learning. With this in mind, the current research was conducted in order to evaluate the types and ratios of feedback teachers use in their physical education classes. A 5-point likert-type measuring instrument, which was adapted by the researcher and consisted of 35 questions, was used in the research. Test-retest value of the scale was found to be .84 ; Cronbach alpha internal consistency value $(\alpha)$ was found to be .81 . In the data analysis, frequencies, percentages, and $t$ test were used, and the significance level was determined as 0.05 . The results show that in the students' evaluation, feedback is used on a large scale in physical education and sports lessons. No significant difference was found when the teachers' feedback usage rates were compared according to the gender variable of the students or the gender of the teachers $(p>0.05)$. According to the class variable, the difference between the scores of the 8th and 9 th grade students was significantly in favour of the 8th grade students $(\mathrm{p}<0.05)$. Regarding whether lessons took place in a gym or not, the difference between the scores of students studying at the gym and those not studying at the gym was found to be significantly in favour of the group not studying at the gym $(\mathrm{p}<0.05)$.
\end{abstract}

Keywords Physical Education and Sports Lessons, Feedback, Student, Teacher

\section{Introduction}

In general, individuals who are trained for behavioural change are expected to have behavioural changes in the desired direction. The most crucial element of the education system is education itself, which is a process that students acquire. This process is 'learning' from the point of view of the student and 'teaching' from the perspective of the teacher [43]. When problems arise during instruction, they must be identified and eliminated immediately in order for the student to be able to function properly and gain the desired behaviour. The main aim of a sports student who tries to actualise the learning process is to reduce the frequency of making wrong movements and increase the frequency of making correct movements. It is therefore necessary for the individual to know the mistakes he has made and to be informed about how to correct them; that is, the movement of the individual [37]. Feedback, according to researchers ([6]; [38]; [18]; [53]), is information about the nature and quality of the movement, given at the end of a performance or during the performance. According to Mason and Bruning [28], the answer to a message given through the learner's movement is called feedback. Although many definitions appear in different sources, the most general form of feedback is outsourced information on the performance [12], and at the end of the process, learning can be done correctly and quickly [37]. Doig [14] defines feedback as help for the individual learner to achieve the desired outcome according to certain criteria.

Feedback provides information about what people are doing wrong or right, as well as how close they are to the desired results [42]. It also provides meaningful experiences in acquiring knowledge and skills [46]. Since feedback is outsourced information [40] to change the cognition, motivation, or behaviour of the learners in respect of some aspects of the performance of their task, the most important factor is the learning environment, and feedback has a direct influence on the learning process. Teaching-context feedback includes information about the actual situations of learning and / or performance for students [29], [30]. According to cognitive psychologists, feedback helps the individual to determine the validity of 
the cognition strategy he uses for his protection, reconstruction, and knowledge. While positive feedback points to the individual reaching the target exactly, feedback that includes what the individual is missing or doing wrong warns the student and supplies the cognitive strategies needed to correct their approach [38]. In addition, good-quality and timely feedback are key features in supporting effective student learning processes and benefitting the development of student / teacher relationships [22]. Ryan, Connell, and Deci [34] say that teacher feedback is also important in terms of students' internal motivation. In particular, positive informative feedback increases students' perception of competence, leading to a corresponding increase in student performance and internal motivation. As a result, feedback provided to the students also helps to restructure the information they have received by giving detail about the correctness of their understanding or its inaccuracy, and how to make appropriate arrangements in the cognitive schema while preserving it [38]. Much research suggests that feedback is an important learning tool and element of learning [19], and that feedback is indispensable for learners ([5]; [16]; [23]). Without frequent and accurate feedback, students develop motor skills wrongly or are misled and in such a way, students' acquisition and achievement of skills is prevented [44]. Through feedback, learners get valuable information that enables them to learn quickly and accurately. When feedback is not given, learning takes considerably longer and is often incorrect. There are a number of functions that are critical factors in effective teaching. The first provides information about the performance of the learner, and this can enable adjustments during subsequent experiments. Secondly, feedback can reinforce the skills learners have performed correctly. Finally, the information received by way of feedback provides motivation for a learner's progression [53]. It is important that the interpretation of students' feedback and its content are made available to the students. According to Yorke [54], the content, reception and awareness of feedback is crucial for students' learning. Gibbs and Simpson [16] emphasise the importance of feedback being understandable, timely and actionable by students.

Since feedback is seen as a critical teaching function, researchers in sports pedagogy have shown interest in confirming its importance in physical education. In physical education and sports lessons, it is very important for the student to be given appropriate feedback, because it will affect skills-learning. In effective teaching, knowledge of the student's reasoning, reason for doing, and way of doing should be provided and taught correctly on the basis of the development of the learners' cognitive abilities from the beginning of learning the skill [51]. The use of feedback in physical education classes is important both in terms of skill-learning and the permanence of that learning. In physical education classes, the perception of the learning environment may affect the individual's response. The quality and quantity of the feedback is important and the perception of the student can influence the improvement of existing knowledge, skills and attitude in the next action [26].

\section{Methodology}

\section{Research Aim}

In this article, it is aimed to evaluate the forms of feedback used by teachers for students in physical education courses, in order to provide suggested solutions to problems on the basis of feedback expressions used and feedback usage rates (in the student dimension).

\section{Sample and Data Collection}

In the study, in Sivas province centre, primary education 2nd, 8th and 9th grade students supported by the Ministry of National Education were defined as the universe, each class was accepted as a layer, and 811 students were included in the stratified sampling method.

As a data collection tool, a measuring tool adapted by the researcher was used. The developed scale was first discussed with the teachers, then a pool of questions was created and the questions in the pool were limited by experts in the field (seven physical education and sports teachers, three physical education and sports teaching staff and one measurement evaluation expert). The questions were organised into two groups: demographic information and feedback information. The scale was composed of 35 questions, 25 of which were related to demographic information and 10 of which were related to feedback on a 5 likert type scale. The limits of the expressions and given weights were: 1 = "Never 1.00-1.80", 2 = "Rarely 1.81 2.60", 3 = "Sometimes 2.61-3.40", 4 = "Frequently 3.414.20 " and $5=$ "Always 4.21-5.00".

Scale; have been made available by experts for coverage. Factor analysis was applied to the construct validity, the KMO measure was found to be .893 , and the data were found to be suitable for factor analysis. In the Basic Components Factor Analysis using Varimax transformation, 25 questions were collected under four factors: feedback forms, feedback types, feedback expressions and feedback properties are suitable to size of the study. Factor load values range from .44 to .89 . Among these factors, the percentage of a single factor in the total was found to be 25.43 . The reliability of the test was found to be .84; cronbach alpha internal consistency value $(\alpha)$ was found to be .81 . These values indicate that the scale has a high level of internal consistency, and the reliability and validity values indicate that the scale is appropriate [7]. 


\section{Analyzing of Data}

In the analysis of the data, frequencies, percentages were analysed using the "t" test. Significance level was determined as 0.05 in statistical calculations.

\section{Findings / Results}

Table 1 shows that $439(54.1 \%)$ of the students participating in the research were female and 372 (45.9\%) were male. $221(27.3 \%)$ of the students, were in middle school (8th grade) and $590(72.7 \%)$ of them were in high school (9th grade). In the survey, 87 (10.7\%) students attended lectures given by female physical education and sports teachers and $724(89.3 \%)$ students, attended lectures by male teachers. $506(62.4 \%)$ of the students stated that their lessons took place in a gym, whereas 305 (37.6\%) stated that their lessons took place elsewhere, because no gym was available.

Table 1. Characteristics of the study group

\begin{tabular}{|c|c|c|c|}
\hline Variables & Characteristics & $\mathrm{n}$ & $\%$ \\
\hline \multirow{2}{*}{ Gender } & Female student & 439 & 54.1 \\
\hline \multirow{2}{*}{ Class } & Male student & 372 & 45.9 \\
\hline \multirow{2}{*}{ Gym } & $\begin{array}{c}\text { 8th Grade (middle } \\
\text { school) }\end{array}$ & 221 & 27.3 \\
\hline \multirow{2}{*}{$\begin{array}{c}\text { 9th Grade (high school) } \\
\text { Gender }\end{array}$} & Have & 590 & 72.7 \\
\hline & Have not & 506 & 62.4 \\
\hline
\end{tabular}

Table 2. Engagement Participation Rates for Feedback Usage

\begin{tabular}{|c|c|c|c|c|c|c|c|c|}
\hline Expressions & $\mathrm{N}$ & $\bar{x}$ & $\mathrm{Sd}$ & Never & Rarely & Sometimes & Often & Always \\
\hline Verbal feedback usage rates related to motion & 809 & 3,99 & 1,00 & $\begin{array}{c}16 \\
(\% 2)\end{array}$ & $\begin{array}{c}81 \\
(\% 10)\end{array}$ & $\begin{array}{c}69 \\
(\% 8.5)\end{array}$ & $\begin{array}{c}367 \\
(\% 45.3)\end{array}$ & $\begin{array}{c}276 \\
(\% 34)\end{array}$ \\
\hline Visual feedback usage rates for motion & 810 & 2,98 & 1,34 & $\begin{array}{c}134 \\
(\% 16.5)\end{array}$ & $\begin{array}{c}222 \\
(\% 27.4)\end{array}$ & $\begin{array}{c}91 \\
(\% 11.2)\end{array}$ & $\begin{array}{c}246 \\
(\% 30.3)\end{array}$ & $\begin{array}{c}117 \\
(\% 14.4)\end{array}$ \\
\hline $\begin{array}{l}\text { Both verbal and visual feedback usage rates related to } \\
\text { motion }\end{array}$ & 805 & 3,38 & 1,25 & $\begin{array}{c}61 \\
(\% 7.5)\end{array}$ & $\begin{array}{c}182 \\
(\% 22.4)\end{array}$ & $\begin{array}{c}124 \\
(\% 15.3)\end{array}$ & $\begin{array}{c}264 \\
(\% 32.6)\end{array}$ & $\begin{array}{c}174 \\
(\% 21.5)\end{array}$ \\
\hline $\begin{array}{c}\text { Consequence information utilisation rates related to the } \\
\text { result of the motion }\end{array}$ & 802 & 3,57 & 1,27 & $\begin{array}{c}65 \\
(\% 8) \\
\end{array}$ & $\begin{array}{c}125 \\
(\% 15.4)\end{array}$ & $\begin{array}{c}130 \\
(\% 16) \\
\end{array}$ & $\begin{array}{c}244 \\
(\% 30.1) \\
\end{array}$ & $\begin{array}{c}238 \\
(\% 29.3) \\
\end{array}$ \\
\hline $\begin{array}{c}\text { Process information usage rates related to the process } \\
\text { of motion }\end{array}$ & 804 & 4,03 & 1,15 & $\begin{array}{c}31 \\
(\% 3.8)\end{array}$ & $\begin{array}{c}86 \\
(\% 10.6) \\
\end{array}$ & $\begin{array}{c}76 \\
(\% 9.4) \\
\end{array}$ & $\begin{array}{c}245 \\
(\% 30.2)\end{array}$ & $\begin{array}{c}366 \\
(\% 45.1) \\
\end{array}$ \\
\hline Descriptive feedback usage rates defining errors & 809 & 3,85 & 1,18 & $\begin{array}{c}43 \\
(\% 5.3)\end{array}$ & $\begin{array}{c}93 \\
(\% 11.5)\end{array}$ & $\begin{array}{c}99 \\
(\% 12.2)\end{array}$ & $\begin{array}{c}276 \\
(\% 34) \\
\end{array}$ & $\begin{array}{c}298 \\
(\% 36.7)\end{array}$ \\
\hline Corrected corrective feedback usage rates of faults & 808 & 4,24 & 1,03 & $\begin{array}{c}19 \\
(\% 2.3)\end{array}$ & $\begin{array}{c}55 \\
(\% 6.8)\end{array}$ & $\begin{array}{c}75 \\
(\% 9.2)\end{array}$ & $\begin{array}{c}219 \\
(\% 27)\end{array}$ & $\begin{array}{c}440 \\
(\% 54.3)\end{array}$ \\
\hline Feedback rates after each action & 797 & 3,65 & 1,14 & $\begin{array}{c}38 \\
(04.7)\end{array}$ & $\begin{array}{c}113 \\
(\% 13.9)\end{array}$ & $\begin{array}{c}136 \\
(\% 16.8)\end{array}$ & $\begin{array}{c}308 \\
(038)\end{array}$ & $\begin{array}{c}202 \\
(\% 249)\end{array}$ \\
\hline $\begin{array}{l}\text { Summary feedback use rates in the sense of specific } \\
\text { trial end general evaluation }\end{array}$ & 805 & 3,60 & 1,86 & $\begin{array}{c}46 \\
(\% 5.7)\end{array}$ & $\begin{array}{c}114 \\
(\% 14.1)\end{array}$ & $\begin{array}{c}155 \\
(\% 19.1)\end{array}$ & $\begin{array}{c}289 \\
(\% 35.6)\end{array}$ & $\begin{array}{c}201 \\
(\% 24.8)\end{array}$ \\
\hline $\begin{array}{l}\text { The average utilisation rate feedback with a number of } \\
\text { trial last average value }\end{array}$ & 809 & 3,64 & 1,16 & $\begin{array}{c}38 \\
(\% 4.7)\end{array}$ & $\begin{array}{c}127 \\
(\% 15.7)\end{array}$ & $\begin{array}{c}140 \\
(\% 17.3)\end{array}$ & $\begin{array}{c}287 \\
(\% 35.4)\end{array}$ & $\begin{array}{c}217 \\
(\% 26.8)\end{array}$ \\
\hline $\begin{array}{l}\text { Program feedback usage rates, which include } \\
\text { information on all of the movements and their shape }\end{array}$ & 811 & 3,98 & 1,10 & $\begin{array}{c}30 \\
(\% 3.7)\end{array}$ & $\begin{array}{c}71 \\
(\% 8.8)\end{array}$ & $\begin{array}{c}107 \\
(\% 13.2)\end{array}$ & $\begin{array}{c}280 \\
(\% 34.5)\end{array}$ & $\begin{array}{c}323 \\
(\% 39.8)\end{array}$ \\
\hline $\begin{array}{c}\text { Parameter feedback usage rates including information } \\
\text { about moving parts and direction }\end{array}$ & 808 & 4,02 & 1,08 & $\begin{array}{c}23 \\
(\% 2.8)\end{array}$ & $\begin{array}{c}77 \\
(\% 9.5)\end{array}$ & $\begin{array}{c}96 \\
(\% 11.8)\end{array}$ & $\begin{array}{c}269 \\
(\% 33.3)\end{array}$ & $\begin{array}{c}343 \\
(\% 42.2)\end{array}$ \\
\hline \begin{tabular}{|c|}
$\begin{array}{c}\text { Immediate feedback rates provided immediately after } \\
\text { movement }\end{array}$ \\
\end{tabular} & 805 & 3,48 & 1,13 & $\begin{array}{c}42 \\
(\% 5.2) \\
\end{array}$ & $\begin{array}{c}131 \\
(\% 16.2) \\
\end{array}$ & $\begin{array}{c}191 \\
(\% 23.6) \\
\end{array}$ & $\begin{array}{c}279 \\
(\% 34.4) \\
\end{array}$ & $\begin{array}{c}162 \\
(\% 20) \\
\end{array}$ \\
\hline Delayed feedback rates after a few seconds & 782 & 3,12 & 1,21 & $\begin{array}{c}74 \\
(\% 9.1)\end{array}$ & $\begin{array}{c}192 \\
(\% 23.7)\end{array}$ & $\begin{array}{c}197 \\
(\% 24.3)\end{array}$ & $\begin{array}{c}199 \\
(\% 24.5)\end{array}$ & $\begin{array}{c}120 \\
(\% 14.8)\end{array}$ \\
\hline Value expressions such as "hit was successful" & 806 & 4,13 & 1,06 & $\begin{array}{c}23 \\
(\% 2.8)\end{array}$ & $\begin{array}{c}63 \\
(\% 4.8)\end{array}$ & $\begin{array}{c}82 \\
(\% 10.1) \\
\end{array}$ & $\begin{array}{c}250 \\
(\% 30.8)\end{array}$ & $\begin{array}{c}388 \\
(\% 47.8)\end{array}$ \\
\hline $\begin{array}{c}\text { Use rates of neutral (neutral) expressions such as "run } \\
\text { the distance for } 10 \text { seconds" }\end{array}$ & 808 & 3,20 & 1,26 & $\begin{array}{c}104 \\
(\% 12.8)\end{array}$ & $\begin{array}{c}140 \\
(\% 17.3)\end{array}$ & $\begin{array}{c}181 \\
(\% 22.3)\end{array}$ & $\begin{array}{c}254 \\
(\% 31.3)\end{array}$ & $\begin{array}{c}129 \\
(\% 15.9)\end{array}$ \\
\hline Unclear expression rates such as "Not bad", "Well" & 801 & 3,14 & 1,30 & $\begin{array}{c}97 \\
(\% 12)\end{array}$ & $\begin{array}{c}196 \\
(\% 24.2)\end{array}$ & $\begin{array}{c}143 \\
(\% 17.6)\end{array}$ & $\begin{array}{c}225 \\
(\% 27.7)\end{array}$ & $\begin{array}{c}140 \\
(\% 17.3)\end{array}$ \\
\hline $\begin{array}{c}\text { Qualitative expression usage ratios such as "Leading } \\
\text { the hand of the ball" }\end{array}$ & 789 & 3,98 & 1,12 & $\begin{array}{c}28 \\
(\% 3.5)\end{array}$ & $\begin{array}{c}72 \\
(\% 8.9)\end{array}$ & $\begin{array}{c}119 \\
(\% 14.7)\end{array}$ & $\begin{array}{c}235 \\
(\% 29)\end{array}$ & $\begin{array}{c}335 \\
(\% 41.3)\end{array}$ \\
\hline $\begin{array}{c}\text { Quantitative expression usage rates such as "the sum of } \\
\text { the hand of the hand must be } 20 \mathrm{~cm} \text { ahead" }\end{array}$ & 806 & 3,64 & 1,19 & $\begin{array}{c}45 \\
(\% 5.5)\end{array}$ & $\begin{array}{c}112 \\
(\% 13.8)\end{array}$ & $\begin{array}{c}167 \\
(\% 20.6)\end{array}$ & $\begin{array}{c}244 \\
(\% 30.1)\end{array}$ & $\begin{array}{c}238 \\
(\% 29.3)\end{array}$ \\
\hline $\begin{array}{c}\text { Positive phrase usage rates such as "I think you can do } \\
\text { better" }\end{array}$ & 807 & 3,90 & 1,23 & $\begin{array}{c}58 \\
(\% 7.2)\end{array}$ & $\begin{array}{c}70 \\
(\% 8.6)\end{array}$ & $\begin{array}{c}94 \\
(\% 11.6)\end{array}$ & $\begin{array}{c}250 \\
(\% 30.8)\end{array}$ & $\begin{array}{c}335 \\
(\% 41.3)\end{array}$ \\
\hline $\begin{array}{c}\text { Negative use rates such as "You are not using your } \\
\text { potential" }\end{array}$ & 807 & 2,56 & 1,35 & $\begin{array}{c}234 \\
(\% 28,9)\end{array}$ & $\begin{array}{c}201 \\
(\% 24.8)\end{array}$ & $\begin{array}{c}143 \\
(\% 17.6)\end{array}$ & $\begin{array}{c}139 \\
(\% 17.1)\end{array}$ & $\begin{array}{c}90 \\
(\% 11.1)\end{array}$ \\
\hline $\begin{array}{l}\text { Feedback rates when necessary due to excessive } \\
\text { turnover dependence }\end{array}$ & 807 & 3,37 & 1,17 & $\begin{array}{c}59 \\
(\% 7.3) \\
\end{array}$ & $\begin{array}{c}132 \\
(\% 16.3)\end{array}$ & $\begin{array}{c}225 \\
(\% 27.7)\end{array}$ & $\begin{array}{c}233 \\
(\% 28.7)\end{array}$ & $\begin{array}{c}158 \\
(\% 19.5)\end{array}$ \\
\hline $\begin{array}{c}\text { Rates of thinking about how feedback increases } \\
\text { motivation }\end{array}$ & 793 & 4,02 & 1,11 & $\begin{array}{c}32 \\
(\% 3.9)\end{array}$ & $\begin{array}{c}63 \\
(\% 7.8) \\
\end{array}$ & $\begin{array}{c}104 \\
(\% 12.8)\end{array}$ & $\begin{array}{c}245 \\
(\% 30.2)\end{array}$ & $\begin{array}{c}349 \\
(\% 43) \\
\end{array}$ \\
\hline $\begin{array}{c}\text { Perceptions of positive feedback regarding right } \\
\text { movement }\end{array}$ & 807 & 3,93 & 1,09 & $\begin{array}{c}23 \\
(\% 2.8) \\
\end{array}$ & $\begin{array}{c}79 \\
(\% 9.7) \\
\end{array}$ & $\begin{array}{c}135 \\
(\% 16.6) \\
\end{array}$ & $\begin{array}{c}257 \\
(\% 31.7) \\
\end{array}$ & $\begin{array}{c}313 \\
(\% 38.6) \\
\end{array}$ \\
\hline $\begin{array}{c}\text { Perceptions of negative feedback regarding wrong } \\
\text { movement }\end{array}$ & 810 & 2,97 & 1,41 & $\begin{array}{c}173 \\
(\% 21.3)\end{array}$ & $\begin{array}{c}138 \\
(\% 17)\end{array}$ & $\begin{array}{c}178 \\
(\% 21.9)\end{array}$ & $\begin{array}{c}171 \\
(\% 21.1)\end{array}$ & $\begin{array}{c}150 \\
(\% 18.5)\end{array}$ \\
\hline
\end{tabular}


In Table 2, the participation rates in different kinds of feedback used by physical education and sports teachers in the lessons of the students are given. When the table is examined, students were most likely to report that physical education and sports teachers frequently used motion-related verbal feedback (367 people (\%45.3)), visual feedback (246 people (30.3\%)), verbal and visual feedback (264 persons $(32.6 \%)$ ), consequence information on the result of the action (244 persons (30.1\%)), information about the process (245 people $(30.2 \%)$ ), descriptive feedback describing errors (276 people (34\%)), feedback after each activity (308 people (38\%)), a general evaluation based on specific trials (298 people (\%35.6)), feedback based on averages from a series of trials (287 people (35.4\%)), feedback provided immediately after the movement (279 persons (34.4)), and delayed feedback given a few seconds after the end of the movement (199 people $(24.5 \%))$. A majority of students reported that physical education and sports teachers always used feedback correcting mistakes (440 persons (54.3\%)), program feedback on all movements and their shape (323 persons (\%39.8)), and parameter feedback on all movements and their shape (343 persons (42.2\%)). According to the students, when physical education and sports teachers gave feedback they frequently used neutral expressions (254 people (31.3\%)), ambiguous expressions (225 people $(27.7 \%)$ ) and quantitative expressions (244 people $(30.1 \%)$ ). However, according to a majority of students, teachers were always using qualitative expressions: positive expressions (335 people (41.3\%)) and value expressions (388 people $(47.8 \%)$; a majority thought that negative statements were never used (234 people $(28.9 \%)$ ). They also stated that they frequently participated in feedback's addicted feature $233(28.7 \%)$ ), and always participated in feedback that increased motivation (349 (43\%)). 313 persons $(38.6 \%)$ stated that feedback regarding the right movement provides positive reinforcement. A majority of students (178 persons $(21.9 \%))$ stated that they sometimes felt there was negative reinforcement after the wrong movement.

Table 3. $\mathrm{t}$ Test Results between Feedback Usage Rates by Gender

\begin{tabular}{|c|c|c|c|c|c|}
\hline Gender & $\mathbf{N}$ & $\bar{x}$ & Sd & t & $\mathbf{p}$ \\
\hline $\begin{array}{c}\text { Female } \\
\text { Student }\end{array}$ & 439 & 89,76 & 14,69 & \multirow{2}{*}{0,061} & 0,075 \\
\cline { 1 - 4 } $\begin{array}{c}\text { Male } \\
\text { Student }\end{array}$ & 372 & 89,70 & 15,92 & & \\
\hline
\end{tabular}

$(\mathrm{p}>0.05)$

When Table 3 was examined, the difference between the scores of female students $(89.76 \pm 14.69)$ and male students $(89.70 \pm 15.92)$ was found not to be significant $(p>$ $0.05)$.

Table 4. $\mathrm{t}$ Test Results between Feedback Usage Ratios According to Grade Level

\begin{tabular}{|c|c|c|c|c|c|}
\hline Gender & $\mathbf{N}$ & $\bar{x}$ & Sd & t & p \\
\hline $8^{\text {th }}$ Grade & 224 & 91,51 & 13,80 & \multirow{2}{*}{2,051} & \multirow{2}{*}{$0,026^{*}$} \\
\hline $9^{\text {th }}$ Grade & 587 & 89,05 & 15,74 & & \\
\hline
\end{tabular}

$*(\mathrm{p}<0.05)$
When Table 4 was examined, the difference between the scores of the 8th grade students $(91.51 \pm 13.80)$ and of the 9th grade students $(89.05 \pm 15.74)$ was found to be significant $(\mathrm{p}<0.05)$.

Table 5. $\quad \mathrm{t}$ Test Results between Feedback Usage Rates According to the Gender of the Teacher Entering the Course

\begin{tabular}{|c|c|c|c|c|c|}
\hline Gender & $\mathbf{N}$ & $\bar{x}$ & Sd & t & p \\
\hline Female & 87 & 91,63 & 12,63 & \multirow{2}{*}{1,226} & \multirow{2}{*}{0,075} \\
\hline Male & 724 & 89,50 & 15,54 & & \\
\hline
\end{tabular}

$(\mathrm{p}>0.05)$

Table 5 shows that, although when it came to using feedback according to the gender of the participants, female teachers' rates of feedback usage $(91.63 \pm 12.63)$ were higher than those of the male teachers $(89.50 \pm 15.54)$, in the $t$ test results the gender difference was not significant in the students' evaluations ( $\mathrm{p}>0.05)$.

Table 6. Results of Student's $t$ Test Results between Feedback Usage Ratios According to Course Tasks at the Gym

\begin{tabular}{|c|c|c|c|c|c|}
\hline Gender & $\mathbf{N}$ & $\overline{\boldsymbol{x}}$ & $\mathbf{S d}$ & $\mathbf{t}$ & $\mathbf{p}$ \\
\hline Have Gym & 506 & 88,34 & 16,14 & \multirow{2}{*}{$-3,694$} & $0,001^{*}$ \\
\cline { 1 - 4 } $\begin{array}{c}\text { Have not } \\
\text { Gym }\end{array}$ & 305 & 92,04 & 13,37 & & \\
\hline
\end{tabular}

$*(\mathrm{p}<0.05)$

When Table 6 is examined, the difference between the scores of the students taking classes in a gym $(88.34 \pm$ 16.14) and those students who did not take classes in a gym $(92.04 \pm 13.37)$ were found to be significant in the $t$ test results $(p<0.05)$. This difference stems from the fact of the high scores among the non-gym group.

\section{Discussion and Conclusions}

The students reported that their physical education and sports teachers frequently used verbal feedback (367 people $(45.3 \%)$ ), visual feedback (246 people $(30.3 \%))$ or both verbal and visual feedback (264 people (32.6\%)). In light of technological advances, it is known that video can be used as an additional feedback method [33]; furthermore, short video displays are well accepted by the students because they provide richer content than verbal feedback alone ([1]; [8]; [32]). Kangalgil and Demirhan [25] investigated the effects of different types of feedback (verbal, visual, verbal + visual) given by teachers, analysing accessibility and permanence in the processing of topics within an elementary, 8th grade, physical education basketball unit. Verbal feedback as well as visual feedback was seen to be even higher than verbal + visual feedback.

According to the students, the teachers often reported information about the result of the movement 244 persons (30.1\%), and information about the process (245 people $(30.2 \%))$, gave explanatory feedback describing mistakes 
(276 people (34\%)), gave feedback after each movement (308 people (38\%)), special feedback intended to make a general evaluation of a certain number of trial results (298 people $(35.6 \%)$ ), the mean feedback after a certain number of experiments 287 persons (35.4\%), instant feedback immediately after the movement (279 people (34.4)), and delayed feedback (199 people (24.5\%)), given a few seconds after the end of the movement.

A majority of students reported that physical education and sports teachers always gave corrective feedback (440 people $(54.3 \%))$, program feedback (323 persons $(39.8 \%)$ ) with information on the type of movement, and feedback which contains information about the moving part and direction (343 persons $(42.2 \%)$ ). Teachers frequently used neutral expressions (254 persons $(31.3 \%))$, ambiguous expressions (225 persons $(27.7 \%))$ and quantitative expressions (244 persons $(330.1 \%)$ ), but the students most often thought that the teachers giving feedback always used qualitative expressions 335 people $(41.3 \%)$, positive expressions 335 people (41.3\%) and value expressions 388 people $(47.8 \%)$; negative statements were most often thought to be never used (234 people (28.9\%)). Students also found that they frequently participated in feedback addiction (233 persons $(28.7 \%)$; It was thought by a majority of students that feedback related to motion increases motivation (349 people (43\%)), and feedback regarding the correct movements provides positive reinforcement (313 persons (38.6\%)). The students stated that sometimes they received negative reinforcement after the wrong movement (178 persons $(21.9 \%)$ ).

According to the literature, effective feedback must be systematic, corrective, positive [39], and promptly given ([10]; [31]). Precise, immediate and frequent feedback on learning increases the effectiveness of learning for school-age children [49]. If feedback is delayed, the degree of error increases; there is repetition of mistakes in the acquisition phase and the learner does not learn correctly [20]. Tzetzis and Votsis [47] investigated the effects of three different types of feedback on survival in two situations of different degrees of difficulty (short backhand service - easy), badminton skill (long forehand service - difficult); it was stated that teachers' corrective feedback according to skill level had a great effect on skill permanence. Zacharias [55] investigated the attitudes of students towards feedback given by a teacher. One hundred students participated in the survey and a questionnaire was applied. According to the results of the research, the students asked the teachers to give feedback. However, students stated that the special feedback given by the teachers is more effective. Although students were happy about teachers giving them feedback, they often complained about inconsistent information. Moreover, according to the results of the research, it was reported that feedback given by the teacher contributed to the emotional state of the student, and especially his or her level of motivation. Fredenburg et al. [15] investigated the influence of feedback on skill, technique and performance. The research was carried out with four groups: 1) a group given motivational feedback; 2) a group given feedback comprising information about the task; 3) a group given both information and motivational feedback and 4) a control group. According to the results of the research, there was no significant difference between the groups, but feedback providing information about complex skills was found to be effective in the areas of learning, technical and talent acquisition.

Feedback can be positive or negative. While some researchers advocate that all feedback must be positive [35], others argue that negative feedback can motivate [36]. In fact, some researchers argue that the balanced use of positive and negative feedback is most effective [52]. In the study by Silverman et al. [41], seven teachers taught volleyball service and the forearm pass to seven classes, comprising a total of 202 middle school students, for two weeks. Students were divided into three groups according to pre-test skill levels (low, medium and high). All groups were given the same type and amount of feedback. When positive, corrective and general feedback was given, all students at the high skill level showed great progress in service throw, whereas when negative feedback was given, there was a decline in medium-skill-level female students. While feedback is needed for learning process, the feedback does not have the same effect on every learner ([4]; [17]). Tittelbach et al. [45] found that different feedback sources did not affect performance. Research suggests that the content of feedback and variation in its nature have different learning outcomes for students ([15]; [21]).

Research has shown that both video feedback and verbal feedback are more effective than internal feedback. Dillon and Dempsey [13] worked with a control group and a research group on catching a ball in flight in order to investigate the effect of time-delayed video feedback on learners' cognitive levels and skill acquisition. According to their results, the feedback given by an additional teacher, based on the video, led to the best scores in the final tests, both cognitive and related to catching skills. After the study, researchers noted that it may be useful to use time-delayed video feedback as an educational technology in physical education classes. In addition, the use of technology in conjunction with verbal feedback is likely to make the student more engaged with innovation [11]. The use of technology can be very time consuming, however, in terms of teaching and learning [19].

Providing feedback on individual performance increases self-motivation [3] and motor learning, but it is more advantageous to provide feedback on major faults than minor faults, and it improves motor behaviour. Chiviacowsky and Wulf [9] also pointed out that giving feedback after poor practice rather than feedback after good practice encourages the practitioner to do better, increases motivation, and achieves the desired results more 
quickly. Voight and Callaghan [50] reported that teamwork and feedback on team cohesion and performance of two university women's soccer teams were found to work more effectively when team members were also using communication and feedback between themselves.

There was no significant difference between female students $(89.76 \pm 14.69)$ and male students $(89.70 \pm 15.92)$ ( $>0.05$ ) when the feedback use rates of the teachers were compared according to the sex variables of the students. That is to say, the feedback that teachers use is the same for female and male students. The difference between the scores of the 8th grade students $(91.51 \pm 13.80)$ and the scores of the 9th grade students $(89.05 \pm 15.74)$ was significant in the $t$ test results according to the class variable $(p<0.05)$. This difference appears to be due to the high scores of the 8th grade students and means that more feedback is given to students who are studying in the lower classes. It is important that feedback is interpreted and presented to students for use. According to Yorke [54], feedback content is crucial for learning feedback and awareness. In order for the feedback to be beneficial, students need to have a concept of a target or to adopt relevant actions to compare their standard performance with the goal and close the gap [21].

Regarding the factor of the teacher's gender in students' evaluation of course feedback utilization rates, according to $t$ test results, there was no significant difference between the scores of female teachers $(91.63 \pm 12.63)$ and male teachers $(89.50 \pm 15.54)$, despite the higher rise $(\mathrm{p}>0.05)$. In research conducted by Kangalgil [24] regarding usage rates and types of feedback taking into account the gender of the teachers, the difference between the feedback rates of female teachers and male teachers was found to be significant $(\mathrm{p}<0.01)$. Although both groups had high feedback utilisation rates, female teachers' scores were found to be higher than male teachers' scores. Ülper [48] emphasised that women offer much more feedback as one of the significant differences in their research in terms of gender variation.

The difference between the scores of students who studied in a gym $(88.34 \pm 16.14)$ and the scores $(92.04 \pm$ 13.37) of those who did not was found in the results of the $t$ test to be significant $(\mathrm{p}<0.05)$. This difference stems from the high scores of the group who took their lessons outside the gym. While there is no study to support this interpretation, it can be explained by the theory that outside the hall, the attention of the students is scattered and the teacher may have used more feedback because there are a lot of variables in the process of the course. However, the impact of feedback on learning can be influenced by many factors; for example, the level of skill and knowledge of the student, the type of skill involved, the types of skills displayed the type of feedback provided by the teacher, and the factors behind the teacher feedback [27].

Teacher feedback is the focus of much research, and teacher behaviours and interactions with students are often discussed. Assessment of the feedback utilisation rates of physical education and sport teachers by students will guide teachers in their lessons. Teacher feedback enhances students' motivation, perception and willingness, and students' success is directly related to the amount and quality of feedback they receive and therefore, it is of special importance that the physical education and sports teachers are guided in this way.

\section{Acknowledgements}

Fatih Özgül is the corresponding author of this paper. This study was presented as an oral presentation in The IX. International Congress of Educational Research (Ordu-2017). This work is supported by the Scientific Research Project Fund of Cumhuriyet University under the project number BED-014.

\section{REFERENCES}

[1] Abrahamson, E. (2010). Assessment through video-feedback on an undergraduate sports rehabilitation programme. Higher Education Academy [HEA] Case Study. Retrieved from.

http://www.heacademy.ac.uk/assets/hlst/documents/case_st udies/147_abrahamson_video-feedback.

[2] Adams, E., Rollings, A. (2007). Fundamentals of Game Design. Upper Saddle River, NJ: Pearson Education, Inc.

[3] Badami, R., Vaez Mousavi, M., Wulf, G., Namazizadeh, M. (2011). Feedback After Good Versus Poor Trials Affects Intrinsic Motivation. Research Quarterly for Exercise and Sport, 82, 360-364.

[4] Biesinger, K., Crippen, K. (2010). The Effects of Feedback Protocol on Self-Regulated Learning in a Web-Based Worked Example Learning Environment. Computers \& Education, 55(4), 1470-1482.

[5] Biggs, J. B. (2003). Teaching for Quality Learning at University: What the Student Does. Maidenhead, UK: Society for Research into Higher Education \& Open University Press.

[6] Butler, D. L., Winne, P. H. (1995). Feedback and Self-Regulated Learning: A Theoretical Synthesis. Review of Educational Research, 65, 245-281.

[7] Büyüköztürk, Ş. (2003). Data Analysis Handbook for Social Sciences: Statistics, Research Design, SPSS Practices and Interpretation. Improved 3rd Edition Ankara: Pegem A Publishing.

[8] Cann, A. J. (2007). Podcasting is Dead. Long Live Video! Bioscience Education, 10 (C1). www.bioscience.heacademy.ac.uk/journal/vol10/beej-10-C 1.pdf

[9] Chiviacowsky, S., Wulf, G. (2007). Feedback After Good Trials Enhances Learning. Research Quarterly for Exercise 
and Sport, 78, 40-47.

[10] Coulter, G. A., Grossen, B. (1997). The Effectiveness of in-Class Instructive Feedback versus After Class Instructive Feedback for Teachers Learning Direct Instruction Teaching Behaviors. Effective School Practices, 16, 21-35.

[11] Crook, A., Mauchline, A., Maw, S., Lawson C., Drinkwater R., Lundqvist, K., Orsmond, P., Gomez S., Park, J. (2012) The Use of Video Technology for Providing Feedback to Students: Can it Enhance the Feedback Experience for Staff and Students? Computers \& Education (58) 386-396

[12] Delgado, A. R., Prieto, G. (2003). The Effect of Item Feedback on Multiple-Choice Test Responses. British Journal of Psychology, Vol. 94, pp. 73-85.

[13] Dillon, S., R., Dempsey, K. (2008) Time-Delayed Video Feedback in Physical Education: A Pilot Study 2008 AAHPERD National Convention and Exposition. http://aahperd.confex.com/aahperd/2008/finalprogram/pape r_11673.htm

[14] Doig, S.,M. (1997). Developing an Understanding of the Role of Feedback in Education.

http://www.tedi.uq.edu.au/conferences/A_conf/papers/doig. html

[15] Fredenburg, K. B., Lee, A. M., Solmon, M. (2001). The Effects of Augmented Feedback on Students' Perception and Performance. Research Quarterly for Exercise and Sport, 72(3), 232-242.

[16] Gibbs, G., Simpson, C. (2004). Conditions under Which Assessment Supports Students' Learning. Learning and Teaching in Higher Education, 1, 3-31.

[17] Gordijn, J., Nijhof, W. J. (2002). Effects of Complex Feedback on Computer-assisted Modular Instruction. Computers \& Education, 39, 183-200.

[18] Harrison, J. M., Blakemore, C. L., Buck, M. M. (2001) Instructional Strategies for Secondary School Physical Education. ( $5^{\text {th }}$ Edition). New York, Mcgraw-Hill Higer Education.

[19] Hattie, J., Timperley, H. (2007). The Power of Feedback. Rewiew of Educational Research. Vol. 77, No. 1, pp. 81-112

[20] Heward, W. (1997). Four Validated Instructional Strategies. Behavior and Social Issues, 7, 43-48.

[21] Higgins, R., Hartley, P., Skelton, A. (2002). The Conscientious Consumer: Reconsidering the Role of Assessment Feedback in Student Learning. Studies in Higher Education, 27(1), 53-64.

[22] Irons, A. (2008). Enhancing Learning through Formative Assessment and Feedback. Key Guides for Effective Teaching in Higher Education. Abingdon, UK: Routledge.

[23] Juwah, D., Macfarlane-Dick, B., Matthew, D., Nicol, D., Smith, B. (2004). Enhancing Student Learning Through Effective Formative Feedback. York, UK: The Higher Education Academy.

[24] Kangalgil, M. (2013) The Evaluation of Feedback Usage in Physical Education and Sports Lessons in Terms of Teacher's Dimension. Education and Science 38 (170):384-400
[25] Kangalgil M., Demirhan G. (2008). The Effects of Different Types of Feedback on Success in Physical Education Lessons. FIEP World Congress. Sport Institute of Finland Vierumäki, Finland. p. 48.

[26] Koka A., Hein, V. (2006). Perceptions of Teachers' Positive Feedback and Perceived Threat to Sense of Self in Physical Education: A Longitudinal Study. European Physical Education Review [DOI: 10.1177/1356336X06065180] Volume12(2):165-179:065180

[27] Magill, R. A. (2004) Motor Learning and Control: Concepts and Applications. ( $7^{\text {th }}$ ed.) New York: McGraw-Hill

[28] Mason, B. J., Bruning, R. (2001). Providing Feedback in Computer-Based Instruction: What the Research Tells Us. Retrieved April 5, 2004, From http://dwb.unl.edu/edit/mb/masonbruning.html

[29] Narciss, S. (2006). Informatives Tutorielles Feedback. (Informative tutorial feedback). Münster, Germany: Waxmann.

[30] Narciss, S. (2008). Feedback Strategies for Interactive Learning Tasks. In J. M. Spector, M. D. Merrill, J. J. G. Van Merrie"nboer, M. P. Driscoll (Eds.), Handbook of Research on Educational Communications and Technology (3rd ed.). (pp. 125-143) Mahwah, NJ: Erlbaum.

[31] O’Reilly, M. F., Renzaglia, A., Lee, S. (1994). An Analysis of Acquisition, Generalization and Maintenance of Systematic Instruction Competencies by Preservice Teachers Using Behavioral Supervision Techniques. Education and Training in Mental Retardation and Developmental Disabilities, 29, 22-33.

[32] Rodway-Dyer, S., Dunne, E. (2009). Technology Enhanced Feed-Forward for Learning. HEA Final Report. Retrieved from.

http://www.heacademy.ac.uk/assets/EvidenceNet/Exeter.do c

[33] Rucci, J., Tomparowski, P. (2010). Three Types of Kinematic Feedback and the Execution of the Hang Power Clean. Journal of Strength and Conditioning Research, 24, 771-778.

[34] Ryan, R. M., Connell, J. P., Deci, E. L. (1985). A Motivational Analysis of Self-Determination and Self-Regulation in Education. In C. Ames, \& R. E. Ames (Eds.), Research on motivation in education: The classroom milieu (pp. 13-51). New York: Academic Press.

[35] Scheeler, M.C., Ruhl, K. L., Mcafee, M. K. (2004). Providing Performance Feedback to Teachers: A review. Teacher Education and Special Education, 27, (4) 59-70.

[36] Schelfhout, W., Dochy, F., Janssens, S. (2004). The use of Self, Peer, and Teacher Assessment as a Feedback System in a Learning Environment Aimed at Fostering Skills of Cooperation in an Entrepreneurial Context. Assessment and Evaluation in Higher Education 29, (2) 177-1201.

[37] Schmidt, R. A., Wrisberg, C. A. (2004) Motor Learning and Performance. ( $3^{\text {rd }}$ ed.) Champaign IL: Human Kinetics Publishers.

[38] Senemoğlu, N. (2000) Development Learning and Teaching. Theoretical Application. Ankara: Gazi Bookstore. 
[39] Sharpe, T., Lounsbery, M., Bahls, V. (1997). Description and Effects of Sequential Behavior Practice in Teacher Education. Research Quarterly for Exercise and Sports, 68. 222-232.

[40] Shute, V. (2008). Focus on Formative Feedback. Review of Educational Research, (78), 153-189.

[41] Silverman, S., Tyson, L., Krampitz, J. (1993). Teacher Feedback and Achievement: Mediating Effects of Initial Skill Level and Sex. Journal of Human Movement Studies. 24, 91-98.

[42] Smith, P. L., Ragan, T. J. (2005). Instructional Design (3rd ed.). Hoboken, NJ: Wiley.

[43] Sönmez, V. (1993) Programme Improvement Teacher Handbook Goals. Behaviour. Content. General-Private Teaching Methods. Evaluation. Ankara: Adim Publishing.

[44] Taylor, S. L. (2006). A Study of The Effectiveness of Modern Digital Imaging Techniques with Middle School Physical Education Students During the Development and Acquisition of Motor Skills. Unpublished Doctoral Dissertation. The Florida State University College of Education.

[45] Tittelbach D., Fields, L., Alvero, A. M. (2008) Effects of Performance Feedback on Typing Speed and Accuracy, Journal of Organizational Behavior Management, 27: 4, 29-52 To link to this Article: DOI: $10.1300 / J 075 v 27$ n04_02

[46] Tunstall, P., Gipps, C. (1996). Teacher Feedback to Young Children in Formative Assessment: a Typology. British Educational Research Journal, 22 (4), 389.
[47] Tzetzis, G., Votsis, E. (2006). Three Feedback Methods in Acquisition and Retention of Badminton Skills. Perceptual and Motor Skills. Vol: 102, 275-284

[48] Ülper, H. (2012). Features of Feedback Provided by Teachers to Draft Texts. Education and Science. Cilt 37, Say1 165

[49] Van Houten, R. (1980). Learning Through Feedback. New York, NY: Human Sciences Press, Inc.

[50] Voight, M., Callaghan, J. (2002). A Team Building Intervention Program: Application and Evaluation with two University Soccer Teams. Journal of Sports Behavior, 24, $420-431$.

[51] Wang, J., Griffin, M. (1998). Early Correction of Movement Errors Can Help Student Performance. Journal of Physical Education, Recreation and Dance. Vol: 69, No:4

[52] Weaver, M. R. (2006). Do Students Value Feedback? Student Perceptions of Tutors' Written Responses. Assessment and Evaluation in Higher Education 31, (3) 379-94.

[53] Wuest, D. A., Bucher, C. A. (2006) Foundations of Physical Education, Exercise Science, and Sport. (15 ${ }^{\text {th }}$ Edition) New York: McGraw-Hill.

[54] Yorke, M. (2003) Formative Assessment in Higher Education: Moves towards Theory and the Enhancement of Pedagogic Practice, Higher Education, 45, 477-501.

[55] Zacharias, N., T. (2007) Teacher and Student Attitudes toward Teacher Feedback, Journal of Language Teaching and Research, Vol. 38, No. 1, 38-52. 